\title{
In vitro Plant Regeneration of Four Local Varieties of Chickpea (Cicer arietinum L.) Grown in Bangladesh
}

\author{
T. A. Banu*a, R. H. Sarker ${ }^{b}$ and M. I. Hoque ${ }^{b}$ \\ ${ }^{a}$ Plant Tissue Culture Section, Biological Research Division, Bangladesh Council of Scientific and Industrial \\ Research, Dhanmondi, Dhaka-1205 and ${ }^{b}$ Department of Botany, University of Dhaka, Bangladesh
}

\begin{abstract}
In vitro regeneration system was developed through direct organogenesis from decapitated mature embryo explants of locally grown four chickpea varieties, namely, Barichhola-4, Hyprochhola, Binachhola-3 and Binachhola-4. Best response towards multiple shoot regeneration was obtained on MS medium supplemented with $0.5 \mathrm{mg} / 1 \mathrm{BAP}, 0.5 \mathrm{mg} / 1 \mathrm{Kn}, 0.2 \mathrm{mg} / 1 \mathrm{NAA}$ along with double concentrations of $\mathrm{CaCl}_{2}$ and $\mathrm{NH}_{4} \mathrm{NO}_{3}$. However good shoot health and expanded leaf was found on MS medium containing $1.0 \mathrm{mg} / \mathrm{kn}$. Apart from this, few experiments were conducted with decapitated embryo attached cotyledon. Using this explants highest number of multiple shoots were obtained on MSB medium containing $4 \times$ micronutrients of MS medium with $3.0 \mathrm{mg} / 1 \mathrm{BAP}$ and $0.04 \mathrm{mg} / 1 \mathrm{NAA}$ in all four varieties. Shoots regenerated on $1.0 \mathrm{mg} / \mathrm{kn}$ supplemented medium showed good response towards rooting on MS medium supplemented with $0.2 \mathrm{mg} / 1$ IBA in all four varieties. It was observed that micrografting is an alternative technique to in vitro rooting in chickpea.
\end{abstract}

Key words: In vitro regeneration, Decapitated embryo, Chickpea.

\section{Introduction}

Chickpea is considered as an important pulse crop in IndoPak-Bangladesh subcontinent and consumed by majority of the people of these countries. Chickpea is rich in protein (generally high in lysine) and especially important for those countries where malnutrition is associated with acute shortage of animal protein production (Bressani 1973). Along with the proteins it also supply a good proportion of carbohydrates, fats and minerals. It improves soil fertility by fixing atmospheric nitrogen.

Chickpea is highly nutritious and required minimal inputs for its cultivation. However, this crop is characterized by low yield potential. The national productivity and per capita availability of this crop is very low in Bangladesh (Khan et al. 1981) $7 \mathrm{~g} /$ day, which is compared to $49 \mathrm{~g} /$ day in India (Johl 1984). A number of biotic and abiotic stresses are severely affecting full realization of the yield potential of this crop. Among the biotic stresses the most important fungal diseases are Botrytis gray mold (Botrytis cinerea), Fusarium wilt (Fusarium oxysporum), Alternaria blight (Alternaria alternata), fungal blight (Ascochyta rubici), dry root rot (Rhizoctonia bactaticola), and collar rot (Sclerotium rolfsii). Botrytis gray mold, the most damaging foliar disease of

* Corresponding author: E-mail: : tanzinabcsir@yahoo.com chick pea in Bangladesh, caused a substantial decline in chick pea production over the past decade. Some pests such as Heliothis sp, Callosobruchus chinensis and C. maculatus causes much damage of seeds in storage condition.

Therefore, to obtain desired performance like disease and pest resistance cultivars, improvement of this crop is essential. In the past several attempt was made to develop disease resistant high yielding varieties of chickpea. However, due to cross-incompatibility and hybrid sterility it has not been possible to develop such improved chickpea varieties through conventional breeding methods.

Under this circumstances, genetic transformation technique offers new hope, as specific genes from any source conferring desired traits can be introduced into a crop to overcome certain constraints that limit crop production and quality (Gardner 1993). Agrobacterium mediated genetic transformation can be one of the methods of choice for chickpea as for years it has been used successfully for transformation of legumes and other dicotyledonous plants. Efficient in vitro plant regeneration system is required for successful crop improvement programs through genetic transformation. 
Several attempts have been made to establish in vitro regeneration protocol on chickpea. (Riazuddin et al. 1988, Rao and Chopra 1989, Malik and Saxena 1992, Barna and Wakhlu 1993, 1994, Suhasini 1994, Dineshkumar et al. 1995, Kumar et al. 1995, Murthy et al. 1996, Polisetty et al. 1997, Jayanand et al. 2003).

However, the in vitro regeneration protocols developed by the researchers in the past tend to be irreproducible (Sarker et al. 2005). Therefore, the in vitro regeneration protocol for chickpea needs to be improved further. There are some reports on some Bari Chhola varieties released by BARI (Bangladesh Agricultural Research Institute), Bangladesh (Sarker et al. 2005); some Bina chhola varieties released by BINA (Bangladesh Institute of Nuclear Agriculture), Bangladesh (Sarker and Awal 1999). But no work has been done combinedly with Bari chhola and Bina chhola which are cultivated throughout this country. With this background, attempts were made to establish an efficient regeneration protocol in different chickpea varieties of Bangladesh.

\section{Materials and Methods}

Four local varieties of chickpea (Cicer arietinum L.) were used in the present investigation namely Barichhola- 4, Hyprochhola, Binachhola-3, Binachhola-4. Among the seeds of these four varieties of chickpea (Cicer arietinum L.) Barichhola- 4 was collected from BARI, Joydebpur, Gazipur and other three varieties namely Hyprochhola, Binachhola-3 and Binachhlola-4 were collected from BINA, Mymensingh.

Seeds were surface sterilized according to the protocol described by Sarker et al. (2003) and soaked over night in sterile distilled water or cultured in water- agar medium for germination.

Decapitated mature embryo axes and decapitated mature embryo attached to the cotyledons were used as explants from overnight soaked seeds. The seeds were split open and mature embryo devoid of shoot and root meristems were taken as decapitated mature embryo axes explants.

For shoot initiation and development all the explants were cultured on MS (Murashige and Skoog, 1962) or MSB (MS salts and $\mathrm{B}_{5}$ (Gamborg et al. 1968) vitamins) medium with various hormonal supplements namely BAP, Kn, NAA, In certain combinations, MS macrosalt namely $\mathrm{CaCl}_{2}$ and $\mathrm{NH}_{4} \mathrm{HO}_{3}$ were used in higher concentrations than those in normal MS. For rooting, 3-5 $\mathrm{cm}$ long regenerated shoots were cultured on full or half strength of MS medium supplemented with various concentrations of IBA. All the cultures were maintained under 16 hours photoperiod at $25 \pm 2^{\circ} \mathrm{C}$.

Sometimes healthy shoots, which were unable to induce roots, were grafted onto rootstocks taken from aseptically germinated 6 days old seedlings. The upper part of the rootstock was made a split cut with the help of a fine pointed scalpel and the cut of lower part of the scion (shoot) was made "V" shaped. After placing the scion onto the stock, thin cotton threads were used to tie the attachment region. The entire operation was done inside a laminar flow cabinet. Grafted shoots were cultured in test tubes containing $1 / 2 \mathrm{MS}$ medium without any growth regulators. The plantlets with well-developed root system were transplanted in sterilized soil in small pots.

\section{Results and Discussion}

For in vitro regeneration of shoots two type of explants like decapitated embryo axes (DE) and decapitated embryo attached with cotyledon (DEC) were used. No remarkable variation was observed among the varieties regarding shoot regeneration on a particular medium and hormonal combination.

In the present study, different concentrations of BAP, $\mathrm{Kn}$, NAA, $\mathrm{GA}_{3}$ were used singly or in combinations in MS and MSB medium to observe their effect on initiation and development of shoots. In all the four varieties maximum number of multiple shoots regenerated from both $\mathrm{DE}$ and DEC explants on MSB medium containing $4 \times$ microsalts, $3.0 \mathrm{mg} / 1$ BAP and 0.04 mg/l NAA. Kar et al. (1996) first reported this combination in case of mature embryo axes explant. In the present experiment, it was observed that the above combination was the best for DEC explant (Fig. 2,3 and 4), but not suitable for DE explants, as shoot regenerated from this explants were thin, pale green with very few leaves and sometimes caused callus formation.

Healthy, green shoots with expanded leaves were obtained on MS medium containing $1.0 \mathrm{mg} / \mathrm{l} \mathrm{Kn}$ in case of both DE and DEC explants in all varieties of chickpea (Figs. 5, 6 and 7).But number of shoots per explant was low, maximum three shoots per explant were observed ( Table I). Fontanna et al. (1993) first used this medium composition. 

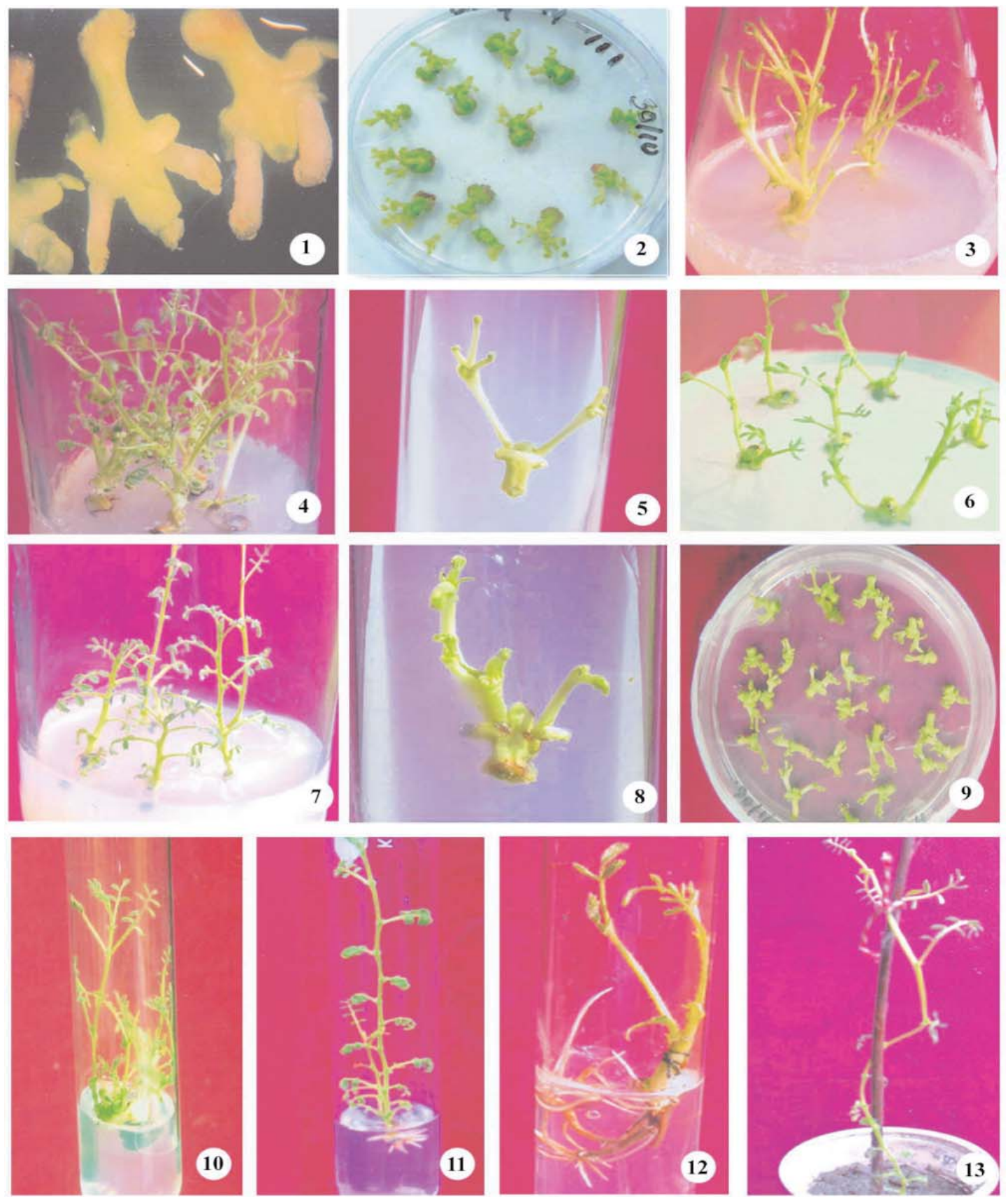

Fig. 1-13. Plant regeneratiom and acclimatization of chickpea.1. Steriomicroscopic view of shoot initiation from decapitated embryo (DE). 2. Multiple shoot regeneration from DE of Binachhola-4 on MSB medium with 4x micronutreients, $3.0 \mathrm{mg} / \mathrm{l}$ BAP and $0.04 \mathrm{mg} / \mathrm{l} \mathrm{NAA.} \mathrm{3-4}$. Multiple shoot formation of Barichhola-4 from decapitated embryo attached cotyledon (DEC) in same medium. 5. Shoot initiation from DE of Binachhola4 on MS medium with $1.0 \mathrm{mg} / \mathrm{l} \mathrm{Kn}$. 6-7. Shoot elongation of Barichhola-4 and hyprochhola in the same medium. 8-9. Multiple shoot initiation from DE of Barichhola-4 and Binachhola-4 on MS medium with 0.5 $\mathrm{mg} / \mathrm{l} \mathrm{BAP,} 0.5 \mathrm{mg} / \mathrm{l} \mathrm{Kn}, 0.2 \mathrm{mg} / \mathrm{l} \mathrm{NAA}$ with $2 \mathrm{x} \mathrm{CaCl}_{2}$ and $2 \mathrm{x} \mathrm{NH}_{4} \mathrm{NO}_{3}$. 10. Shoot elongation of Hyprochhola in same medium . 11. Root initiation on MS medium with $0.2 \mathrm{mg} / \mathrm{l} \mathrm{IBA}$ in Hyprochhola. 12. In vitro grafting in Barichhola-4. 13. Acclimatization of Hyprochhola in pot soil. 
Krishnamurthy et al. (2000) used MS medium containing 0.5 $\mathrm{mg} / \mathrm{l}$ BAP for shoot regeneration using embryo axes explants. Similar concentration was used in this experiment and observed that regenerated shoots were initially pale green with very few developing leaves. In a separate set of experiments, $0.5 \mathrm{mg} / \mathrm{l} \mathrm{BAP}, 0.5 \mathrm{mg} / \mathrm{Kn}$ alone and in combination with NAA was applied in MS medium for shoot regeneration and development. Sarmah et al. (2004) used similar type of hormonal combinations in shoot regeneration medium and reported successful regeneration. Among all media and hormonal combinations tested the best response was observed in MS medium supplemented with $0.5 \mathrm{mg} / 1$ BAP, $0.5 \mathrm{mg} / \mathrm{Kn}$ and $0.2 \mathrm{mg} / \mathrm{l} \mathrm{NAA}$ from decapitated mature embryo explants in all four varieties. The mean number of shoots was 6-7.5 per explant, but shoot tip death was observed eventually.

Ye et al. (2002) reported that MS medium with double concentration ( $2 \times$ normal MS medium) of $\mathrm{CaCl}_{2}$ could overcome shoot tip death in lentil. In the present investigation, two fold concentration ( $2 \times$ normal medium) of $\mathrm{CaCl}_{2}(880$ $\mathrm{mg} / \mathrm{l}$ ) and some other macro-nutrients, e.g. potassium nitrate $(3800 \mathrm{mg} / \mathrm{l})$ and ammonium nitrate $(3300 \mathrm{mg} / \mathrm{l})$ were used singly or in combination in shoot regeneration medium. Among the various combinations of macro-salts, $2 \times \mathrm{CaCl}_{2}$ $(880 \mathrm{mg} / \mathrm{l})$ and $2 \times \mathrm{NH}_{4} \mathrm{HO}_{3}(3300 \mathrm{mg} / \mathrm{l})$ was proved to be the best for regeneration and development of healthy leafy green shoots and in overcoming shoot tip necrosis. Only Binachhola-3 failed to reduce shoot tip death. Other three varieties showed comparatively better response on this medium. Thus the most suitable media for direct shoot regeneration from DE explant was MS medium supplemented with $0.5 \mathrm{mg} / 1 \mathrm{BAP}, 0.5 \mathrm{mg} / 1 \mathrm{Kn}, 0.2 \mathrm{mg} / 1 \mathrm{NAA}, 2 \times \mathrm{CaCl}_{2}$
$(880 \mathrm{mg} / \mathrm{l})$ and $2 \times \mathrm{NHNO}_{3}(3300 \mathrm{mg} / \mathrm{l})($ figs. 8,9 and 10) in all four varieties( Table I).

There are very few publications reporting successful rooting of chickpea (Singh et al. 1982, Davis and Foster 1982). It has been reported that isolated shoots were successfully rooted if those shoots were regenerated in MS medium containing $\mathrm{Kn}$ (Fontanna et al. 1993, Jayanand et al. 2003, Fratini et al. 2003). Shoots regenerated on BAP containing medium showed lower number of root formation (Kar et al. 1996, Polowick et al. 2004) and in most cases rooting was accomplished through very difficult media pathways (Polowick et al. 2004). All of these reports indicate that rooting of chickpea is extremely difficult. Similar situation was also observed in the present investigation. Those shoots that were developed in $1.0 \mathrm{mg} / \mathrm{l} \mathrm{Kn}$ supplemented media rooted successfully (Fig. 11) than other media combinations in $0.2 \mathrm{mg} / 1$ IBA supplemented with full strength of MS medium. Hyprochhola showed the best rooting response (Table II). The plantlets with well developed roots were transferred to small plastic pots. After proper hardening they were established in field condition (Fig. 13).

The seasonal effect of the four varieties was observed. Shoots regenerated on MS medium supplemented with 0.2 $\mathrm{mg} / \mathrm{l}$ IBA was cultured once in every month. It has been observed that maximum root induction was found when the shoots were cultured during the month of December to February. It was also observed that there was no root induction during the month of June-August. The results showed that there is a significant effect of seasons on the root induction of chickpea. Those shoots that failed to develop roots were subjected to micrografting on root stocks of in vitro germinated seedlings following the report of Krishnamurthy

Table I: Best hormonal combinations for shoot regeneration from decapitated mature embryo axes explants

\begin{tabular}{l|c|c|c|c}
\hline $\begin{array}{l}\text { Media + Hormonal sup- } \\
\text { plement (mg/l) }\end{array}$ & Varieties & $\begin{array}{c}\text { Days required for } \\
\text { shoot initiation }\end{array}$ & $\begin{array}{c}\text { Explants showed rege- } \\
\text { neration response (\%) }\end{array}$ & $\begin{array}{c}\text { Mean no. of shoots/ } \\
\text { explant }\end{array}$ \\
\hline & Barichhola- 4 & $6-8$ & 95.00 & 2.5 \\
$\mathrm{MS}+1 \mathrm{mg} / \mathrm{l} \mathrm{Kn}$ & Hyprochhola & $5-7$ & 96.66 & 3.0 \\
& Binachhola- 3 & $6-8$ & 96.66 & 2.0 \\
$\mathrm{MS}+0.5 \mathrm{mg} / \mathrm{l} \mathrm{BAP+}$ & Binachhola- 4 & $6-10$ & 95.00 & 2.5 \\
$0.5 \mathrm{mg} / \mathrm{Kn}+0.2 \mathrm{mg} / 1$ & Barichhola- 4 & $7-10$ & 96.66 & 6.5 \\
$\mathrm{NAA}+$ & Hyprochhola & $7-10$ & 96.66 & 7.0 \\
$2 \mathrm{X} \mathrm{CaCl}+2 \mathrm{XNH}_{4} \mathrm{NO}_{3}$ & Binachhola- 3 & $8-10$ & 98.33 & 6.0 \\
\hline
\end{tabular}


Table II: Effect of $0.2 \mathrm{mg} / \mathrm{l}$ IBA on semi-solid MS medium for root induction from regenerated shoots of all four varieties

\begin{tabular}{|c|c|c|c|c|c|}
\hline $\begin{array}{l}\text { Shoot regenerated } \\
\text { media }\end{array}$ & Varieties & $\begin{array}{l}\text { No. of shoots inoculat- } \\
\text { ed for root induction }\end{array}$ & $\begin{array}{l}\text { No. of responsive } \\
\text { shoots }\end{array}$ & $\begin{array}{l}\text { Days to root } \\
\text { induction }\end{array}$ & $\begin{array}{c}\text { No. of roots/ } \\
\text { explant }\end{array}$ \\
\hline \multirow[t]{4}{*}{ MS medium with Kn } & Barichhola-4 & 30 & 19 & $7-16$ & $3-5$ \\
\hline & Hyprochhola & 30 & 19 & $7-15$ & $4-8$ \\
\hline & Binachhola-3 & 30 & 15 & $7-16$ & $3-6$ \\
\hline & Binachhola-4 & 30 & 10 & $13-20$ & $2-5$ \\
\hline MS medium with 0.5 & Barichhola-4 & 20 & 4 & $14-20$ & $1-2$ \\
\hline $\mathrm{mg} / 1 \mathrm{BAP}, 0.5 \mathrm{mg} / 1 \mathrm{Kn}$, & Hyprochhola & 20 & 6 & $12-20$ & $2-3$ \\
\hline $0.2 \mathrm{mg} / 1 \mathrm{NAA}, 2 \mathrm{x}$ & Binachhola-3 & 20 & 4 & $14-22$ & $2-3$ \\
\hline macronutrients & Binachhola-4 & 20 & 2 & $18-25$ & $2-3$ \\
\hline
\end{tabular}

et al. (2000), Sarmah et al. (2004) and Senthil et al. (2004). In the present study, among the four varieties Barichhola-4 showed the maximum rate $(46.66 \%)$ of successful grafting.

\section{Conclusion}

The results of the present investigation demonstrated the establishment of a reliable in vitro regeneration protocol from decapitated mature embryo axes and decapitated embryo attached with cotyledon explants for four selected Bangladeshi chickpea varieties. This protocol may be effectively used for the improvement of different chickpea varieties through Agrobacterium- mediated or any other suitable methods of genetic transformation.

\section{References}

Barna K. S. and Wakhlu A. K. (1993). Somatic embryogenesis and plant regeneration from callus cultures of chickpea (Cicer arietinum L.). Plants Cell Rep. 12: 521-524.

Barna K. S. and Wakhlu A. K. (1994). Whole plant regeneration from Cicer arietinum L. from callus cultures via organogenesis. Plant Cell Rep. 13: 510-513.

Bressani R. (1973). Legumes in human diet and how they might be improved. PAG of United Nations System. pp. 15-42.

Davis T. M. and Foster K. W. (1982). A method for rooting chickpea cutting. Int; Chickpea Newsetter. 7: 6.

Dineshkumar V., Kirti P. B., Sachan J. K. and Chopra V. L. (1995). Picloram induced somatic embryogenesis in chickpea (Cicer arietinum L.). Plant Sci. 109: 207-213.

Fontanna G. S., Santini L., Caretto S., Frugis G. and Mariotti, D. (1993). Genetic transformation in the grain legume Cicer arietinum L. (chickpea). Plant Cell Rep. 21: 194198.

Fratini R. and Ruitz M. L. (2003). A rooting procedure for lentil and other hypogeous legumes (pea, chickpea and Lathyrus) based on explant polarity. Plant Cell. Rep. 21: 726-732.

Gamborg O. L., Miller R. A. and Dijma K. (1968). Nutrients requirements of suspension cultures of Glycine species. Plant Cell. Rep. 2: 209-212.

Gardner R. C. (1993). Gene transfer into tropical and subtropical crops. Scientia Hort. 55: 65-82.

Jayanand B., Sudarsanam G. and Sharma K. K. (2003). An efficient protocol for the regeneration of whole plants of chickpea (Cicer arietinum L.) by using axillary meristem explants derived from in vitro germinated seedlings. In vitro Cell Dev. Biol. Plant. 39: 171-179.

Johl S. S. (1984). Food production production and relevance of Agricultural Research in India. XVI Lalbahadur Sastri Memorial Lecture. IARI, New Delhi.

Kar S., Johnson T. M., Nayak P. and Sen S. K. (1996). Efficient transgenic plant regeneration through Agrobacterium-mediated transformation of chickpea (Cicer arietinum L.). Plant Cell Rep. 16: 32-37.

Khan M. R. L., Shaikh M. A. Q. and Dutta P. C. (1981) Nutritional quality characters in pulses. Proc. National 
Workshop of Pulses, BARI, Joydebpur, Dhaka, Bangaldesh. pp. 199-207.

Krishnamurthy K. V., Suhasini K., Sagare A. P., Meixner, M., De Kathen, A. Pickardt and Schieder O. T. (2000) Agrobacterium-mediated transformation of chickpea (Cicer arietinum L.) embryo axes. Plant Cell Rep. 19: 235-240.

Kumar V. D., Kirti P. D., Sachan J. K. S. and Chopra V. L. (1995). Plant regeneration via somatic embryogenesis in chickpea (Cicer arietinum L.). Plant Cell Rep. 13: 468-472.

Malik K. A. and Saxena P. K. (1992). Thidiazuron induced high frequency shoot regeneration in intact seedlings of pea, chickpea (Cicer areietinum L.) and Lentil. Aust. J. Plant Physiol. 19: 731-740.

Murashige T. and Skoog F. (1962). A revised medium for rapid growth and bioassays with tobacco tissue cultures. Physiol. Plant. 15 : 473-497.

Murthy B. N. S., Victor J., Singh R. P., Fletcher R. A. and Saxena P. K. (1996). In vitro regeneration in chickpea (Cicer arietinum L.) Plant Growth Regul. 19: 233-240.

Polisetty R., Paul V., Devenshwar J. J., Khetrapal S., Suresh K. and Chandra R. (1997). Multiple shoot induction by benzyladenine and complete plant regeneration from seed explants of chickpea (Cicer arietinum L.). Plant Cell Reports. 16(8): 565-571.

Polowick P. L., Baliski D. S. and Mahon J. D. (2004) Agrobacterium tumefasciens mediated transformation of chickpea (Cicer arietinum L.): gene integration, expression and inheritance. Plant Cell Rep. 23: 485491.

Rao B. G. and Chopra V. L. (1989). Regeneration of chickpea (Cicer arietinum L.) through somatic embryogenesis. J. Plant Physiol. 134: 637.

Riazuddin S., Husnain T., Malik T., Farooqu H. and Abbas S. T. (1988). Establishment of callus-tissue culture and the induction of organogenesis in chickpea. Pak. J. Agric. Res. 9: 339-335.
Sarker R. H. and Awal T. A. (1999). In vitro morphogenesis in chickpea (Cicer arietinum L.) Plant Tissue Cult. 9(2): 141-150.

Sarker R. H., Mustafa B. M., Biswas A., Mahbub S., Nahar M. Hashem R and Hoque M. I. (2003). Agrobacterium -mediated Transformation of Lentil (Lens culinaris Medik.) Plant Tissue Cult. 13(1): 1-12.

Sarker R. H, Mustafa B. M., Biswas A., Mahbub S., Nahar M., Hashem R and Hoque M. I. (2003). In vitro regenaration of lentil (Lens culinaris Medik). Plant Tissue Cult. 13(2): 155- 163.

Sarker, R.H. Tarannum, T. and Haque, M.I. (2005). In vitro Direct Regeneration of Three Indigenous Chickpea (Cicer arietinum L.) Varieties of Bangladesh. Plant Tissue Cult. 15(2): 135-144.

Sarmah B. K., Moore A. and Tate A. (2004). Transgenic chickpea seeds expressiong high levels of a beanmasylase inhibitor. Plant Cell Reports. 22: 586-599.

Senthil G., Williamson B., Dinkins R. D. and Ramsay G. (2004). An efficient transformation system for chickpea (Cicer areitinum L.) Plant Cell Reprot 23: 297303.

Singh R. P., Singh B. D., Jaiswal H. K., Singh R. M. and Singh R. B. (1982). Organogenesis in callus cultures of chickpea. Indian J. Agric. Sci. 52: 86.

Suhasini K., Sagare A. P. and Krishnamurthy K. V. (1994). Direct somatic embryogenesis from mature embryo axes in chickpea (Cicer arietinum L.). Plant Sci. 102: 189-194.

Ye G. Menell, D. L. Conner A. J. and Hill G. D. (2002). Multiple shoot formation in lentil (Lens culinaris) seeds. New Zealand J. Crop. and Hort. Sci. 30: 1-8.

Received: July 15, 2010;

Accepted : January 31, 2011 